\title{
Social aspects of meat eating
}

\author{
BY NICK FIDDES \\ Department of Social Anthropology, The University of Edinburgh, Adam Ferguson Building, \\ George Square, Edinburgh EH8 $9 L L$
}

The present paper explores the way that culture conditions our dietary behaviour, and also, conversely, how what we choose to eat can inform us about our own identities as members of Western society and as human beings. Understanding the value system that underpins our society (however little we may be conscious of it in our daily lives) is necessary to illuminate a true social science of food, to explain why we endow animal flesh with its unique status and, thence, to suggest whether our rapidly changing view of this singular substance is a fashion or a trend. But first, a brief history of the social science of food may be useful. The influence of diet on human health and behaviour has been discussed since time immemorial. However, only relatively recently has a systematic body of theory emerged that considers the culture of food selection. acquisition, preparation, and consumption as a significant social phenomenon.

Engels (1844) did write at length one and a half centuries ago on how poor diet contributed towards the condition of the working class in England, but really only as an indicator of what was to him a more significant economic analysis. By and large, all the classic sociologists such as Marx, Durkheim, and Weber tended to mention food habits only in the context of their deeper concerns, although Herbert Spencer (1898-1900) considered such issues as religious and military aspects of foods, and corpulence as a sign of affluence. Veblen (1899) took this further in The Theory of the Leisure Class, detailing how food and drink are routinely employed for conspicuous consumption.

Simmel's (1910) essay on the sociology of the meal stressed the use of food in ritual and religious ceremony, and the meanings of communal cating. Perhaps it is here that we begin to see the first real appreciation of how both the form and content of a meal can denote much more than its actual food value, although W. Robertson Smith (1889) had commented several years earlier that 'those who eat and drink together are by this very act tied to one another by a bond of friendship and mutual obligation .

As the 20th century progressed, appreciation of food's centrality to human behaviour advanced rapidly. Radcliffe-Brown (1922) proposed that for the Andaman Islanders 'by far the most important social activity is the getting of food'. and within a decade Audrey Richards (1939) was producing pioneering work in which she placed the food and nutrition of her African peoples in their social and psychological contexts. One of the most interesting publications, however, is Norbert Elias's (1939) treatise on Western table manners. The Civilising Process, not least for his discussion of how the scrving of meat in European society has developed in a consistent direction since the Middle Ages.

For many years, however, most analyses remained largely descriptive and utilitarian, scrutinizing the functions and curiosities of 'other' people's feeding, but without recognizing that our own 'normal' habits can be equally revealing. This tendency is strikingly exemplified in a genre which typically treats vegetarians and other nonorthodox eaters with barely disguised suspicion, as if their subversive beliefs and behaviour threaten more than just conventional nutritional wisdom (which, I argue, is 
true; they challenge their society's basic cosmology). The discourse often misrepresents the most extreme practices or short-term dietary treatments as if they were typical, and is characteristically laced with terminology of 'crazes' and 'faddism' or even 'psychopathology' that ideologically marginalizes the subjects. But, most regrettably, it fails to apply the same scepticism to the mainstream diet that is, presumably, enjoyed by the researchers.

The flourishing of theory came from the likes of Mary Douglas (Douglas, 1966, 1970, 1973, 1975, 1978; Douglas \& Nicod, 1974; Douglas \& Isherwood, 1980), Claude Lévi-Strauss (1963, 1966, 1967, 1969, 1970, 1973, 1978, 1987), and the semiologist Roland Barthes (1975), and their recognition of the extent to which taste is culturally conditioned, and governed by patterned rules. Lévi-Strauss's real concern, in fact, lay with the universal structures of the human mind, but his intricate unpicking of the 'language' of food in different cultures bequeathed a rich heritage of analysis, summed up in his celebrated 'culinary triangle' in which he related the transformation of food between the poles of the raw and the cooked (and the rotten) to categories of nature and culture. Douglas (1975) is particularly famed for Deciphering a Meal in which she revealed the unwritten codes of our society's cuisine, but her work on purity and taboo and a raft of other writings on food, has contributed equally to our understanding.

Recent theory has been concerned less with description than with interpreting society through the symbolic meanings attached to foods and food habits, the practical functions of the eating rituals in which we all participate, the economic and ecological conditioning of dietary habits, and food's use for expressing social or spiritual identity. Since the 1980s, particularly, a lively debate has evolved in the social sciences, supported by an explosion of ethnographic detail.

These interests are by no means mere abstract theory. Rather, they reflect a realization that to study food habits divorced from their entire social context is futile; once we have met basic survival needs, eating becomes a matter of love and belongingness, of self-esteem, and of self-actualization. Indeed, social conditioning can easily override even basic hunger, as when poverty-stricken families give of their last reserves to entertain a guest or, more dramatically, when some victims of the Andes air crash starved themselves rather than resort to cannibalism.

Unfortunately, a tendency to presume a rationality in traditional Western food selection continues to characterize collaboration between social scientists and nutritionists to this day. For example, when a consumer panel reports that they dislike red meat because it is too fatty, or too tough, or too cruel, that is commonly accepted as sufficient explanation, when it should be only a starting point. All-too-easily we presume that it is sensible to avoid fat, or not to want to chew too hard, or even to be squeamish about animals' sensibilities, when we could be asking why these things are of greater concern than 2 , or 20 , or 200 years ago. Similarly, individual consumers might believe that the high cost of meat explains their avoidance. To the market researcher, requesting the motive for their abstention, the explanation may likewise seem reasonable. But there is always room for further enquiry, as an interview of mine once illustrated:

'So why don't you eat meat?'

'Oh, I can't afford it. My boyfriend and I are both living on grants and we just can't manage it.'

'Is that really the only reason?'

'Yes. Absolutely. We just don't have the money. It's far too expensive.' 
'So you still enjoy eating it if you've been invited to dinner by friends or something then?' 'Well, no, I still prefer not to really.'

'What, even if you're not paying?'

'Well, yes. I don't really know why. I just prefer not to. I know it's silly, but we'll usually ask if we can have something else.'

'You must have some idea why, surely? Give me a clue?'

'I don't know. I just don't like the taste.'

'Do you mean you've grown out of liking it after not eating it for so long?'

'No, I don't think it's that. I suppose . . . it's something to do with not liking the thought of . . . I don't know. Just not liking the idea of the animal being . . . killed . . . so that I can eat it. It's horrible.'

Price alone cannot explain the existence of vegetarianism, yet sich 'rational' reasons are commonly accepted at face value. Whilst never reliable, the economist's view can be useful for purely market-oriented studies of people's food habits within strictly delimited spatial and temporal boundaries. But it is next to useless for looking more deeply or more broadly at why people eat or drink as they do, and why long-term preferences change. People may use the language of 'not liking the taste', or of 'health', or of 'the price of meat', because this is the discourse with which most of us feel most comfortable: but the reasons why meat is suddenly being seen as less healthy than it used to be, by scientists as well as by housewives, are much more fundamental. As Mary Douglas (1978) has argued: 'Nutritionists know that the palate is trained, that taste and smell are subject to cultural control. Yet for lack of other hypotheses, the notion persists that what makes an item of food acceptable is some quality inherent in the thing itself. Present research into palatability tends to concentrate on individual reactions to individual items. It seeks to screen out cultural effects as so much interference. Whereas . . . the cultural controls on perception are precisely what needs to be analysed.' What we choose to eat depends as much on our cosmology as on our physiology. We really are what we eat. Just as Buddhist vegetarianism, or Lapp reindeer-hunting, can be understood only with reference to their communities' cosmological complexes, explanation for the high rank meat has enjoyed in the Western classification of potential foodstuffs, and why the market is currently turbulent, must be sought in social history as well as contemporary culture.

It is relatively easy to notice oddities in the behaviour of others. For example, in a classic work on the classification of animals in Thailand, Tambiah (1973) demonstrated that 'values and concepts relating to social relations are underpinned to rules about eating animals [and] we have to inquire for the society in question why the animals chosen are so appropriate in that context to objectify human sentiments and ideas', showing that understanding indigenous geography, mythology, taxonomy, and religion were all prerequisites to deciphering why the forest rat was edible but the civet cat forbidden to pregnant women. To the villagers he studied, of course, their rules would have been self-evident, a matter of taste and tradition: but the anthropologist as 'stranger' can develop an analytical perspective which is hard to achieve from 'within'.

It is, however, more challenging for us to perceive that our own tastes can be equally non-rational. As does every society, we develop rationalizations to explain our habits as 'normal', and we each grow up with little need to question them; it is difficult to perform the role of strangers in the context of our own culture. So let us ask: what might a team of little green observers from the planet Mars make of Western eating habits, if they had 
been studying us all these years? I shall consider briefly three areas of the Western 'meat system' from a Martian perspective: history and prehistory; our definitions of inedible species; and notions of health and nutrition, to reveal culture's part in each. Thereafter, I shall suggest some additional meanings of our culinary tastes.

The aliens' tentacled eyes would first have watched our emergence somewhere in the tropics or sub-tropics, gathering easily available fruits and vegetable matter, supplemented by only the occasional taste of meat from small animals. This is still the way of our closest primate relations. However, over millennia, the Martians would have seen us evolve into societies which control 1.28 billion cattle alone, cattle which use nearly $24 \%$ of the planet's landmass and whose combined weight exceeds that of the human population on earth (Rifkin, 1992) but where meat still is regularly consumed by only a minority of the world's people.

We have colonized the globe as far as the polar reaches, where the habitat affords little else but animal produce. But in most regions, even amongst self-proclaimed 'hunters', vegetable foods provide at least $80 \%$ of nutrition, as has probably always been the case. So-called 'hunter-gatherer' peoples should properly be called 'gatherer-hunters', since flesh is typically the minor component. We can subsist on widely varied diets. Thus, surely the aliens would be intrigued to note that, in common currency, one routine explanation of our liking for the taste of animal flesh is that we are hunters by origin and, therefore, carnivores by nature. They might reasonably conclude that this says more about our preferred self-image than about historic actuality. Similarly, the Martians might wonder why popular history depicts medieval Europeans as exceptionally carnivorous when, in fact, animals were reared mainly for dairy, wool, and traction and, for most people, meat remained a rare luxury. Flesh was eaten in quantity only amongst the rich and powerful, although their consumption could indeed be staggering.

Today, the diversity of ways in which humans eat, and say we eat, is remarkable. Some groups or individuals subsist on little but meat, but claim it a rare aberration. Others seldom consume flesh in practice, yet call themselves hunters. Some profess vegetarianism, yet eat flesh on occasion; not a few Western 'vegetarians' will eat chicken, or bacon, or even hamburgers. We do not by any means always do as we say, for meat's value is symbolic as well as nutritional.

Vegetarianism has long characterized large parts of the world, commonly for religious or economic reasons. But, in the West, whereas once only such eccentrics as Pythagoras or George Bernard Shaw (or particular sectors of society such as monks) advocated a meat-free diet, today it has become the voluntary preference of millions, correlated particularly with women, with urban dwellers, with the young, and with the highly educated. The influence of culture is unmistakable. And yet, our Martians would hear countless millions, including academics, continue to maintain that we are somehow 'meant' to eat meat because of our dentition or the form of our guts; because men especially 'need' it to grow up strong and healthy; or because it is somehow instinctive. Surely the aliens would decide that there was something more going on here than nutrition.

Another aspect of our foodways which extraterrestrial anthropologists might find curious is how we categorize which animals we can eat, and which we should not. They would not be particularly surprised to find that we civilized Westerners do not eat members of our own species; after all, avoiding cannibalism is common amongst animals. But what they might find curious is why we believe that so many other peoples indulge in 
the barbaric act, or have done so in the past. From their vantage point, the aliens might have seen no 'adequate documentation of cannibalism as a custom in any form for any society', but that the "idea of "others" as cannibals, rather than the act, is the universal phenomenon. The significant question is not why people eat human flesh, but why one group invariably assumes that others do' (Arens, 1979).

More curious to the Martians than that, perhaps, would be the way in which the cannibalism taboo seems to permeate our society's categories of edible and inedible. For example, species such as dogs and cats which we have found amenable as companions and houseguests, we tend not only not to eat, but to find abhorrent when we hear of other societies elsewhere who rather enjoy their flavour. Similarly, the idea of eating monkey meat would fill most of us with a deep-seated unease, presumably because other primates remind us too much of ourselves. But this is not a 'rational' taboo: it is an arbitrary cultural association. Other peoples eat monkeys without hesitation.

Perhaps the Martians would be amused that in the British Isles the idea of eating horse meat has become distinctly unacceptable, over a period when horses have become perceived more as social companions than as farm animals, whilst just across a narrow stretch of water their flesh is still enjoyed within another culture. This is hardly rational, but it is understandable.

The disinterested extraterrestrials, therefore, would be unsurprised to find that aspects of our nutritional beliefs are also touched by inconsistency. Indeed, for evidence they would hardly need to look further than the enormous disjunction between physiological needs and 'expert' dietary advice on the one hand, and the contents of the average supermarket trolley on the other, overflowing with nutrient-free diet-colas and desserts concocted from indigestible fats, and a range of colourful packages filled with permutations of fats, sugars, starches, and chemicals. Foods provide pleasure, almost regardless of nutrition. But to the Martians, this would come as little surprise. They would already have seen how meat, which had always generally been seen as a positive boon to good health, suddenly became much more so as the scientific era flourished. Baron Justus von Liebig, in particular, popularized the 'protein myth', by glorifying meat as the essential source of material to replenish muscular strength (Liebig, 1846, 1847). He gave new scientific status to notions that animal food was somehow more nutritious than mere vegetables, and his prestige soon endowed meat with near-magical properties. Liebig $(1846,1847)$ endorsed the erroneous 19 th century view that muscle was destroyed by exercise, and could be replaced only by more protein, or in other words meat, despite his pioneering of artificial fertilizers for plants, and his knowledge of vegetarian communities.

The Martians might reflect how this mythical nutritional quality invested in meat seems to operate through a magical process as much as by 'protein'. It is as if we eat animals' muscle and lifeblood in the hope of making ourselves strong, just as certain American Indians believed that a person who eats venison is swifter and wiser than one who eats 'the slow-footed tame cattle, or the heavy wallowing swine' (Adair, 1775). This, for example, might be why the boxer Lloyd Honeyghan reports he is 'so hungry for success' he's been 'living on raw steak' (Massarik, 1987).

Our aliens would have seen how in countless communities throughout history, the consumption of meat was generally regarded as an unrivalled route to ruddy good health, not least because it tended to make one fat: a certain sign of prosperity. Then they would have seen how, in the late 20th century, fat suddenly became unpopular, just at a time 
when affluence was becoming commonplace. Slimness is a cultural, as much as a medical, injunction. Then they would be struck that, however much it was particular fats in excess that nutritionists condemned, in popular discourse this more often than not seemed to be discussed in terms of meat. So inconsistent is the public that the 'healthier' Vegetarian Society launched its Cordon Vert Cookery courses with a Brazilian Bake that derived $77 \%$ of its energy from fat, and had a content of saturated fat per kg three times that of lean beef.

Then the aliens would have seen how a society which had always placed implicit trust in the beneficence of technology, suddenly started to fear its fruits, expressed in a seemingly endless spate of 'health scares' concerning chemicals, or diseases, or 6-yearold meat. 'Expert' reassurances about the benign processes or compounds fell on deaf ears; consumers seemed to see contagion or contaminants at every turn. The Martians would surely wonder whether all of these 'health' issues might not be in some way expressions of other cultural trends, perhaps, for example, related to the ever more widely circulating concern that technological industrialism might already have gone too far in its impacts upon the natural envrionment. All these things are affected by culture: and if the Martians knew one thing that was entirely predictable about any human culture they had ever seen, it is that nothing stayed the same for long.

I began by stating that understanding the value system that underpins our own culture is necessary to illuminate a true social science of meat. Explanation for meat's peculiar status does exist: however, it rests not in people's conscious motivations and elucidations, but at a far deeper level: our culture's cosmology, tacit assumptions, philosophical premises, spirituality. As with the food systems of every society on earth, we can understand our own diets only with reference to the deep-rooted beliefs by which we are all taught to see the world. In particular, it is to our relationship with the natural world that we must look for clues to meat's social identity. Our belief system in this context can be traced back at least to Aristotle (1984) who said that 'other animals exist for the sake of man'. But throughout much of Western history, our basic cosmology has been represented by interpretations of the Christian message. This diffused an image of the world as a God-given resource for our chosen species to utilize at our will, with a duty to worship the Higher Being, but with few if any responsibilities towards nature. More fundamentally, perhaps, it established a view of humanity as qualitatively separate from the rest of the natural world, just one rung below the angels on the hierarchy of Great Chain of Being, as one of the 'most potent and persistent presuppositions in Western thought' (Lovejoy, 1936). This could be, and was, widely taken to legitimize our right to use the earth with scant consideration for consequences.

Controlling the multiple threats of 'wild' nature must always have been a necessary human goal to some extent, but in recent centuries this need has been elevated to the status of holy grail. What, after all, is the demand for predictability in science, if not the desire for control, for power? Certainly, the notion of human control of nature as an aim as well as a right can be traced through the philosophy of Aquinas, Leibniz and Spinoza, the science of Copernicus, Kepler and Bacon, and the art of Milton, Pope, and Victor Hugo (Lovejoy, 1936). As the historian Keith Thomas (1983) puts it: 'Man's dominion over nature was the self-consciously proclaimed ideal of early modern scientists'.

During the Enlightenment, the Industrial Revolution, the Scientific Revolution, this approach was not abandoned, but was refined and retranslated into the new rationalist idiom. Descartes, perhaps above all, was responsible for defining the mechanistic ethos 
which still prevails throughout much of Western science, by which animals other than humans were claimed to be mere automata analogous to clockwork mechanisms, whilst only humans had eternal souls. (In today's digital age, of course, his mechanical metaphor has been updated to the computer jargon of genetic 'programming'.) This is the ideology which has prevailed in politics, economics, and science, not to mention religion and philosophy, throughout the modern period. To most of us, its premises are so self-evident that we would never think to recognize, let alone challenge, them. Perhaps only by being made aware of how unique modern Western society is, amongst human communities ever studied by anthropologists or understood by historians, in the severity of the spiritual divorce we ordain between ourselves and the world that supports us, can we begin to appreciate this cosmology for what it is: just one world view amongst many possible. The point, here, is that this is what gives meat its power.

Meat's essential value, not just as any old food, but as the food above all others, derives directly from its capacity to represent to us most tangibly our power over the rest of the natural world (Fiddes, 1991). What, after all, is meat? It is the bodies, ideally the muscle, of those beasts we can safely designate our prey. At a cultural level, we like to eat animals in order metaphorically to authenticate our power over them, and by extension over the world at large. Only by understanding this can we make sense of the rest of the meat system. It explains why meat (as well as related activities such as hunting) has long been most highly valued by the wealthy and powerful élites in society, for whom it has served as a means of demonstrating authority. It explains, too, why those who have enjoyed less control over their own lives, such as the poorer social strata, and also women as a group, have been denied access to the same quantities of meat as their more powerful peers. It also explains why those who have chosen to shun earthly power in favour of spiritual control, such as monks and ascetics, have so often chosen abstaining from meat as a central symbol of their voluntary simplicity. Above all, it explains the patterns of meat's supply and demand. It explains why, as the ethos of technological control rose to prevalence, meat consumption rose in parallel: and it explains why, now, that pattern is changing.

The pattern of demand is changing, because the underlying ethos is changing. The assumption of technological control of nature as an unquestioned 'Good' is now being challenged on many fronts. On the one hand, Chaos and the New Physics is saying that predictability is ultimately an impossibility, and control an illusion. From another angle, philosophers are arguing that reductionism is all well and good, but that so much that matters in life cannot be fitted into its strictures, so 'science' as currently constituted should be confined to areas where it is appropriate. But perhaps most influential is the challenge of environmentalism which suggests, quite simply, that control of nature may have gone too far; that its price has been too high in terms of damage to our own habitat, and that we must find a way of redefining our place in nature, if we are to stand any chance of healing our social structures, and ultimately in order to survive.

It is this sea change which is redefining the entire terms of our debate. This is why so many individuals are choosing either not to eat meat, or not to eat the red meats which traditionally have been most strongly associated with power and control. Meat remains the symbol of control as much as ever, but what has changed is that the brute power over nature it embodies is now no longer universally seen as an unqualified good.

This is perhaps most obvious amongst the more radical 'New Age' element of the population, many of whom can phrase at least some of these arguments semi-coherently, 
expounding an explicit rejection of much of the scientific-industrial ideology (though, conveniently, not necessarily of all the technology), and a spiritual system which harks back to animism. A diet of demi-vegetarianism, vegetarianism or veganism is, of course, almost ubiquitous in such circles. But such groups cannot easily be marginalized and discounted, because the ideas which they represent most forcefully are still achieving ever wider currency and influence. And, as environmental issues precipitated by an excess of industrial insensitivity inevitably continue to hit the headlines, there is little likelihood of this trend discontinuing.

We live in a period of rapid change: social, ecological, spiritual, and dietary; change at a rate that is probably unprecedented on a historic time-scale, yet not always obvious in our day-to-day existence. Yet change is not new. Our views of meat, and of all foods, are different from those of our great grandparents; theirs differed radically from those current in the Middle Ages; and doubtless in 50 years time, dietary paradigms will be different again. By its nature, change cannot be predicted from current expectations. That is why so many 'market' studies of food habits are unsatisfactory; they assume that the future will continue present patterns. It never has, so why should it now?

The future cannot be predicted with confidence; but trends are evident, at a social and ecological as well as a dietary-behavioural level, and they are 'rational' in their own terms, if not necessarily always in the terms of policy-makers and scientists. If nutritionists as well as social scientists wish to keep up as progress unfolds, it is vital to understand people's own agendas, rather than to impose an inappropriately rationalist model. Otherwise, the very real danger is that an ever-expanding sector of the population will devise its own new nutritional wisdom, and shop and eat on that basis, with industry and science ill-equipped to respond with other than impotent cries of 'you're wrong!'.

All-too-often, the pattern is for 'authorities' to produce foods in new 'more efficient' ways, only to be shocked by the inevitable consumer backlash of 'irrational' scares and resistance. But normative prescriptions as to nutritional 'facts' are useless if they fail to relate to the population's beliefs and feelings. Food matters to people at a very basic level. A prime example may be the rapidly-advancing field of genetic manipulation of food animals and processes, which is being hastened into operation with scant public information or debate, largely for the private interests of technologists and industrialists. Like any scientific development, the public at large has been slow to realize its full implications, but the technology nonetheless encapsulates much that is feared at a deeply emotional level. It is an archetypal example of the sort of issue which will fuel public fury once the first major ecological or public health disaster occurs. If I can make only one prediction, it is that here is an ideological time-bomb, ticking away.

\section{REFERENCES}

Adair, J. (1775). A History of the American Indians, p. 113. London: Dilly.

Arens, W. (1979). The Man-eating Myth, pp. 21 and 139. New York: Oxford University Press.

Aristotle (1984). Politics. In The Complete Works of Aristotle: The Revised Oxford Translation, pp. 1993-1994

[J. Barnes, editor]. Guildford: Princeton University Press.

Barthes, R. (1975). Towards a psychosociology of contemporary food consumption. In European Diet, From

Pre-industrial to Modern Times, pp. 47-59 [E. Forster and F. Forster, editors]. New York: Harper.

Douglas, M. (1966). Purity and Danger. London: Routledge \& Kegan Paul.

Douglas, M. (1970). Natural Symbols. London: Barrie \& Rockliff.

Douglas, M. (ed.) (1973). Rules and Meanings. Harmondsworth: Penguin. 
Douglas, M. (1975). Deciphering a Meal. In Implicit Meanings, pp. 249-275. London: Routledge \& Kegan Paul.

Douglas, M. (1978). Culture. In Annual Report of the Russell Sage Foundation, pp. 55-81. New York: Russell Sage Foundation.

Douglas, M. \& Isherwood, Baron (1980). The World of Goods. Harmondsworth: Penguin.

Douglas, M. \& Nicod, M. (1974). Taking the biscuit: the structure of British meals. New Society 19, $744-747$.

Elias, N. (1939). The Civilising Process, 1978 ed. New York: Urizon.

Engels, F. (1844). The condition of the working class in England. In Karl Marx, Frederick Engels: Collected Works, vol. 4, 1975 ed. London: Lawrence \& Wishart.

Fiddes, N. (1991). Meat: A Natural Symbol. London: Routledge.

Lévi-Strauss, C. (1963). Structural Anthropology. London: Basic Books.

Lévi-Strauss, C. (1966). The culinary triangle. New Society 166, 937-940.

Lévi-Strauss, C. (1967). The Structural Study of Myth and Totemism. ASA Monographs 5. London: Tavistock.

Lévi-Strauss, C. (1969). The Elementary Structures of Kinship. London: Eyre \& Spottiswoode.

Lévi-Strauss, C. (1970). The Raw and the Cooked. London: Cape.

Lévi-Strauss, C. (1973). From Honey to Ashes. London: Cape.

Lévi-Strauss, C. (1978). The Origin of Table Manners. London: Cape.

Lévi-Strauss, C. (1987). Anthropology and Myth. Oxford: Blackwell.

Liebig, J. (1846). Animal Chemistry, 3rd ed. London: Taylor \& Walton.

Liebig, J. (1847). Researches on the Chemistry of Food. London: Taylor \& Walton.

Lovejoy, A. (1936). The Great Chain of Being, p. vii. Cambridge, Massachusetts: Harvard University Press.

Massarik, J. (1987). Rusty Bruno cautious over Tyson fight. Guardian 26 March, 28.

Radcliffe-Brown, A. R. (1922). The Andaman Islanders, 1964 ed., p. 227. New York: Free Press.

Richards, A. (1939). Land, Labour and Diet in Northern Rhodesia. London: Oxford University Press.

Rifkin, J. (1992). Beyond Beef. New York: Penguin.

Robertson Smith, W. (1889). The Religion of the Semites, p. 247. Edinburgh: Black.

Simmel, G. (1910). Soziologie der mahlzeit (Sociology of the meal). Der Zeitgeist. Supplement to Berliner Tageblatt 19 October. Reprinted in Simmel, G. (1957). Brüche und Tür, pp. 243-250. Stuttgart: K. F. Köhler.

Spencer, H. (1898-1900). The Principles of Sociology, 3rd ed. New York: D. Appleton.

Tambiah, S. J. (1973). Classification of animals in Thailand. In Rules and Meanings, p. 165 [M. Douglas, editor]. Harmondsworth: Penguin.

Thomas, K. (1983). Man and the Natural World, p. 29. Harmondsworth: Penguin.

Veblen, T. (1899). The Theory of the Leisure Class, 1959 ed. London: Allen \& Unwin. 